\title{
Research on the Effectiveness of Application of Tabletop Games in English Vocabulary Learning at Elementary School
}

\author{
Hsin-Hao Chen ${ }^{*}$ I-Chen Wang \\ College of Humanities and Social Sciences, Southern Taiwan University of Science and Technology, Taiwan
}

Received October 19, 2021; Revised December 13, 2021; Accepted December 22, 2021

\section{Cite This Paper in the following Citation Styles}

(a): [1] Hsin-Hao Chen, I-Chen Wang , "Research on the Effectiveness of Application of Tabletop Games in English Vocabulary Learning at Elementary School," Universal Journal of Educational Research, Vol. 10, No. 1, pp. 103 - 116, 2022. DOI: 10.13189/ujer.2022.100110.

(b): Hsin-Hao Chen, I-Chen Wang (2022). Research on the Effectiveness of Application of Tabletop Games in English Vocabulary Learning at Elementary School. Universal Journal of Educational Research, 10(1), 103 - 116. DOI: 10.13189/ujer.2022.100110.

Copyright $\bigcirc 2022$ by authors, all rights reserved. Authors agree that this article remains permanently open access under the terms of the Creative Commons Attribution License 4.0 International License

\begin{abstract}
The purpose of this research is to explore the impact of "tabletop games integrated into English teaching" on the effectiveness of English vocabulary learning and learning attitudes of third-grade students. The research method used is the quasi-experiment. The subjects are two normal classes of students in the third grade of an elementary school in Tainan. They were divided into two groups, experimental group and control group. All of them were allowed to review the English vocabulary learned in the English classroom after school over the research period. The experimental group played tabletop games to review English vocabulary, and the control group used traditional writing and recitation method to review English vocabulary. The test tools include the English vocabulary tests before and after the experiment and feedback questionnaires. Statistical methods such as descriptive statistics, analysis of covariance, independent samples t-test, and paired samples t-test were used for data analysis. The research results included: (1) Both groups of students have made significant progress in "listening comprehension of English vocabulary"; (2) Both groups have made significant progress in "spelling" ability and the average progress the students in the experimental group have made was greater than the students in the control group did; (3) The students in the experimental group as a whole expressed a middle-to-high degree of satisfaction with "tabletop games integrated into English teaching" and have had a positive attitude to it. Finally, specific
\end{abstract}

suggestions were made based on the research results for reference by teachers, schools, and education-related administrative units.

Keywords Tabletop Games, English Teaching, Learning Effectiveness

\section{Introduction}

English has become the language of international communication under the influence of globalization in recent years. In response to the advent of English as the world's most predominant form of communication, people in Taiwan have attached great importance to English as a subject in education. Many County and City Governments have independently increased the English learning courses and allowed first-grade students to begin studying English as a formal course [1]. In 2013, the Mayor of Tainan announced the promotion of English as the second official language in Tainan City and students would take more English learning courses since attending elementary schools. The elementary school students in Tainan City would begin learning English from grade one, so that they would learn English early and not fail at the starting line [1]. In addition, the Ministry of Education [2], following the "2030 Bilingual National Policy", has encouraged the 
masses to learn English and increase English teachers and professional talents. All of these show the importance of English teaching.

Learning a new language involves the four basic language skills: listening, speaking, reading and writing. In addition, vocabulary is an important basis for all language skills [3]. Learning English vocabulary includes spelling, pronunciation, meaning, part of speech, usage, etc. [4]. Students in first and second grades of elementary school learn to recognize and read the 26 English letters. The third-grade students begin to build up their English vocabulary, and they must have the ability to follow the spelling and pronunciation rules (including reading and pronouncing, listening and spelling) of the letters they have learned [2]. For English learners, the acquisition of English vocabulary is a difficult process [5]. Teachers can help students to recite vocabulary by repeating and stressing them in the classroom, but constant repetition can make students feel bored and lose interest in learning English, so teachers can use games to help students memorize vocabulary [4]. The tabletop game does not require sound and light effects or harm eyesight, but enables students to practice language, and are witty and interesting.

There have been many studies on the tabletop games integrated into English vocabulary teaching in Taiwan. However, there have been few studies on English vocabulary learning of students in the third grade of elementary school. The third grade is the stage where students start to learn English vocabulary. Therefore, this research is designed to use tabletop games as the teaching medium and combine them with English vocabulary teaching, to explore the effectiveness of third-grade students' English vocabulary learning, and to allow students to increase their oral practice opportunities in the process of interacting with their peers, hoping to help them improve their word recognition and spelling skills and give them a solid foundation in English learning. The research purposes are:

(1) To explore the effectiveness of using tabletop games to improve third-grade students' listening comprehension of English vocabulary.

(2) To explore the effectiveness of using tabletop games to improve third-grade students' ability to spell English vocabulary.

(3) To explore the attitudes of third-grade students' attitudes towards learning English vocabulary by playing tabletop games.

According to the research purposes, the research questions of this study are:

(1) After tabletop games have been integrated into the third-grade English teaching, have students made significant progress in listening comprehension of English vocabulary? Is the progress much greater than that made by students taught using traditional teaching methods?
(2) After tabletop games have been integrated into the third-grade English teaching, have students made significant progress in their ability to spell English vocabulary? Is the progress much greater than that made by students taught using traditional teaching methods?

(3) What is the attitude of the third-grade students towards using tabletop games to practice English vocabulary?

\section{Literature Review}

\subsection{The Implication of the Effectiveness of English Vocabulary Learning}

The Grade 1-12 Curriculum Guidelines issued by the Ministry of Education stipulate that the third-grade students need to learn the pronunciation rules and spelling of English vocabulary, including the listening comprehension of English vocabulary by and spelling [6] In this research, listening comprehension of English vocabulary refers to is the ability to "understand the meaning of the word after listening to its pronunciation" and to correctly select the picture that corresponds to the English word. The higher the score in the listening test created by the researcher a student has, the better his/her listening comprehension of English vocabulary.

\subsubsection{Information Processing Learning Theory}

Information processing learning theory is an important factor in cognitive learning theory. The key to making learning effective is "memory" [7]. The process of memory includes coding, storing and restoring [8]. "Coding" refers to the way that information is transformed into a form easy for us to remember. "Storing" means storing the information in memory, and "restoring" means recalling the knowledge we have learned.

When failing to retrieve some message, one might have "forgotten" it. The reasons for the forgetting have been explained based on degradation theory and interference theory [9]. Degeneration theory refers to the fading of the memory traces in the brain. The less frequently a message is reviewed, the slighter the relevant memory traces will become, causing difficulty in message retrieval, and thus causing a failure in memory retrieval. According to the Ebbinghaus forgetting curve, after several real-time review of new information, the message can be converted into long-term memory, and after several more reviews, the long-term memory can be maintained [10]. The interference theory means that different messages input to the memory causes interference to the original information. It is divided into proactive interference and retroactive interference. Proactive interference refers to the fact that old information learned in the past affects the retrieval of current information. Retroactive interference 
means that new knowledge interferes with the retrieval of old knowledge [9].

\subsubsection{Vocabulary Learning Strategy}

As mentioned in the theory of information processing, mechanical learning can convert vocabulary into short-term memory, but it is limited in the stage of converting vocabulary into long-term memory. Meaningful learning in the context is crucial to successfully converting vocabulary into long-term memory [7]. Some teachers have proposed that there are two types of vocabulary teaching strategies, presentation of vocabulary (character shape and meaning) and review to strengthen memory (exercise and repetition) [11].

\section{(1) Presentation of vocabulary:}

Most learners get knowledge passively. Although learners are allowed to actively participate in learning activities in some stages, teachers still need to present the spelling and meaning of vocabulary.

\section{(2) Review to strengthen memory:}

The review of vocabulary is aimed to input the vocabulary to long-term memory. According to the spaced repetition [12], one must review it 5-10 minutes after learning an item of knowledge, and then lengthen the space between reviews gradually.

\subsection{Theories of Play and Educational Implication}

The development of theories of play is divided into two stages, classical theories developed before 1920 and modern theories developed after 1920 [13], which is described as follows:

\subsubsection{Classical Play Theories}

Among the classical play theories, the earliest one is the theory of surplus energy. Because children have no pressure in life and have vigorous energy, they need to play to consume their surplus energy and get self-satisfaction [14]. Hall put forward the play recapitulation theory in 1906. He believed that human beings need to play from the beginning and in the process life, and that it is human nature to play [15].

\subsubsection{Modern Play Theories}

Among modern play theories, the cognitive theory holds that play can promote children's educational growth. Piaget believed that children are assimilated and make adjustments in the process of physical and mental development. This process is called adaptation. Play can help children adapt to the outside world of adults. Children can practice new knowledge and skills and old experience by playing, and command the new knowledge and skills they have learned in play [16].

With the evolution and development of play theory, the features of play can be summarized: (1) Play is purposeful, reflects real life, and has the implication of social learning; (2) Play reflects children's need for development, perfusion of imagination, emotional expression and language learning; (3) It is necessary that play is spontaneous and children participate in play activities voluntarily [13].

Based on the scholars' statements mentioned above, play has positive educational implications for children's growth. Play is helpful to the development of children's creativity, concentration, satisfaction, emotions, and problem solving [14]. In terms of education, play can enhance children's learning motivation, stimulate their imagination, and allow them to actively engage in practice activities. Play promotes the socialization of children in terms of entertainment. Children at play need to interact with others and guess their ideas, so that children can develop empathy and social skills, and learn to adjust their mentality and accept the results in the process of winning or losing [17]. Therefore, both parents and educators should provide children with a safe and comfortable environment so that children can learn about themselves, interpersonal relationships and the knowledge needed by society in the game.

\subsection{The Implication of Tabletop Games}

\subsubsection{Features of Tabletop Games}

Tabletop games are also called "unplugged games", which refer to games that can be played smoothly without relying on electronic products [18]. The three core characteristics of tabletop games are: (1) rules; (2) game pieces; (3) fun. The rules refer to the rules and methods of playing games. The game pieces are the subjects that will be used for playing games, such as cards, turntables, etc. Fun is the emotional reaction of players in the game [19].

\subsubsection{The Application of Tabletop Games in the Field of English Vocabulary Teaching}

In recent years, the application of tabletop games in the teaching field has become more and more widespread [20]. Studies have also shown that tabletop games can effectively promote interpersonal relationships, frustration tolerance, problem-solving skills, communication skills and self-confidence [21]. In the English teaching scene, the games integrated into classroom exercises have become a trend [22]. Students can actively participate in game activities through tabletop games and repeatedly practice English vocabulary, sentence patterns and conversations they have learned, to effectively practice English speaking [23].

The literature review results showed that there is only one study that has been carried out in our country on the tabletop games integrated into English vocabulary teaching for third-grade students. The study was conducted by Huang [24] on the third-grade students in 
children's American English class. There were only 7 students as subjects and the cramming school divided students into classes according to their English proficiency, and there was not much difference between the students' level of English proficiency. The third grade of elementary school is an important stage for the start of formal English courses. Developing vocabulary skills will lay a good foundation for future English learning. Therefore, in this study tabletop games were used for English teaching, to explore the students' learning effectiveness, learning perception and learning retention effects in English vocabulary learning, so as to make a contribution to English teaching.

\section{Research Methods}

\subsection{Research Framework and Experimental Design}

\subsubsection{Features of Tabletop Games}

\subsubsection{Independent Variables}

The independent variable of this research is the way of reviewing English vocabulary after formal class. After the formal English class, the teacher used several tabletop games to guide the students to review the vocabulary they had learned in the English classroom. Meanwhile, the control group reviewed English vocabulary using traditional writing and recitation methods.

\subsubsection{Dependent Variables}

The dependent variables of this study are the students' listening comprehension of English vocabulary, spelling ability and learning retention effects. First, the students take the "English Vocabulary Test" created by the researcher before and after the experiment. Next, the researcher will compare and analyze the scores the students get in the tests before and after the experiment (hereinafter referred to as the pre-test score and the post-test score). If the post-test score is higher than the pre-test score, it means that the students' English vocabulary has been improved. The researcher will also compare the scores the experimental group and the control group get in the tests they take immediately and after the experiment (hereinafter referred to as the immediate test score and the delayed test score). The group with higher scores indicates that the learning retention effect of the teaching method applied to the group is better.

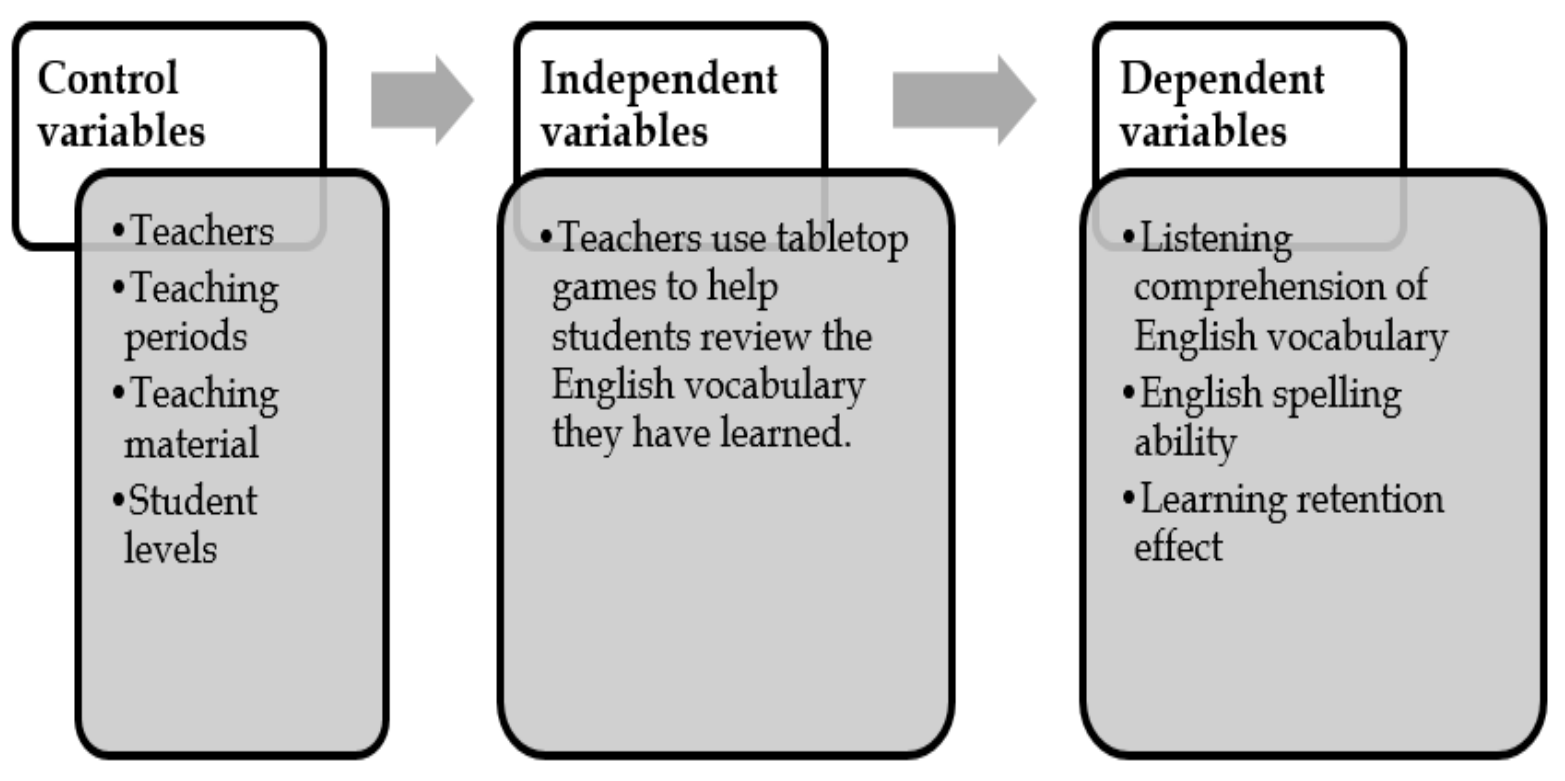

Figure 1. Research structure 


\subsubsection{Control Variables}

There are 4 control variables in this study, which are described as follows:

(1) Teacher: There is only one English teacher who teaches the experimental group and the control group, maintaining a consistent teaching schedule, teaching style and teaching attitude.

(2) Teaching periods: Two formal classes a week, totaling 80 minutes. The period for reviewing vocabulary is 40 minutes a week, lasting for ten consecutive weeks.

(3) Teaching material: The teaching material used is the first volume of "Dino on the Go!" by Han Lin Publishing Co., Ltd. In the experimental stage, the students were learning the vocabulary and sentence patterns of Lesson 3 and Lesson 4.

(4) Student levels: Students in both groups are from normal classes. The students have been distributed in accordance with the S-type normal class grouping and are at the same level. They used the same English learning materials when they were in the first and second grades and had the same initial English proficiency.

\subsubsection{Experimental Design}

This study adopts the "nonequivalent group quasi-experimental design". The experimental design model is shown in Table 1:

Table 1. Experimental design

\begin{tabular}{|c|c|c|c|c|}
\hline Group & Pre-test & $\begin{array}{c}\text { Experimental } \\
\text { treatment }\end{array}$ & Post-test & $\begin{array}{c}\text { Delayed } \\
\text { post-test }\end{array}$ \\
\hline $\begin{array}{c}\text { Experimental } \\
\text { group }\end{array}$ & $\mathrm{T} 1$ & $\mathrm{X}$ & $\mathrm{T} 3$ & $\mathrm{~T} 5$ \\
\hline $\begin{array}{c}\text { Control } \\
\text { group }\end{array}$ & $\mathrm{T} 2$ & & $\mathrm{~T} 4$ & $\mathrm{~T} 6$ \\
\hline
\end{tabular}

Each code represents:

T1: It represents the "English vocabulary test" the students in the experimental group take before the experiment.

T2: It represents the "English vocabulary test" the students in the control group take before the experiment.

T3: It represents the "English vocabulary test" the students in the experimental group take after the experiment.

T4: It represents the "English vocabulary test" the students in the control group take after the experiment.

T5: It represents the "English vocabulary test" the students in the experimental group take after the experiment.

T6: It represents the "English vocabulary test" the students in the control group take after the experiment.

$\mathrm{X}$ : It represents the tabletop game integrated into teaching method applied to the students in the experimental group.
To sum up, this study was designed to conduct a quasi-experiment. First, all the students in the experimental group and the control group took an English test, and then attended English class for ten weeks. Next, the students in the experimental group reviewed English vocabulary by playing tabletop games, and the students in the control group used traditional writing and recitation methods. After that, all of them took another English test and finally the delayed post-test after the ten-week winter vacation.

\subsection{Research Subjects}

With a population of approximately 23.5 million, Taiwan has always attached great importance to education. Children enter the first grade at the age of six. In 1968, the nine-year compulsory education policy was implemented. Then, the length was extended to 12 years in 2014. Tainan is the city with the longest history in Taiwan. It is one of the six largest cities in Taiwan, with a population of nearly 1.9 million. Elementary students in Tainan City need to attend English class since the first grade. This research was carried out at an elementary school in Tainan City. As for the English courses, the first-grade students have one English class a week, and the students in second to sixth grades have two English classes a week. For this research, two normal classes of third-grade students were selected as subjects. The class sizes are similar. The experimental group consists of 20 students, 12 boys and 8 girls, and the control group consists of 22 students, 13 boys and 9 girls.

In order to understand the listening comprehension of English vocabulary and spelling ability of the two classes before teaching. The researcher gave the two groups a test to know their levels of proficiency in English vocabulary. There were 12 questions on the listening comprehension of English vocabulary and 13 questions on spelling. There were 25 questions in total, each worth 4 points. In this study, independent sample t test was used to analyze whether there is a significant difference between students' level of proficiency in English vocabulary. The statistical results showed that the average test scores of the experimental group is 48.00 points and the control group is 50.91 points, with no significant difference, as shown in Table 2. This means the students are suitable subjects of this research.

Table 2. Comparison of scores the two groups of students got in the test before the experiment

\begin{tabular}{|c|c|c|c|}
\hline Vocabulary test & $\begin{array}{c}\text { Average } \\
\text { points }\end{array}$ & $\begin{array}{c}\text { Standard } \\
\text { deviation }\end{array}$ & $\boldsymbol{t}$ \\
\hline $\begin{array}{c}\text { Experimental } \\
\text { group }\end{array}$ & 48.00 & 14.16 & .470 \\
\hline Control group & 50.91 & 24.97 & .458 \\
\hline
\end{tabular}




\subsection{Research tools}

\subsubsection{Listening Comprehension of English Vocabulary Test}

The test was drawn up based on the core vocabulary and alphabet examples of vocabulary in Lesson 3 and Lesson 4 of Book 1. The purpose is to know students' listening comprehension of English vocabulary. Twelve words were selected for the questions. The teacher read the word, and the subjects were required to select the correct picture corresponding to the word they heard.

\subsubsection{Spelling Test}

The test was drawn up based on the core vocabulary and alphabet examples of vocabulary in Lesson 3 and Lesson 4 of Book 1. The purpose is to know the students' spelling ability of English vocabulary. Thirteen words were selected for the questions, and the subjects filled in the letters on the bottom line according to the pictures and alphabet prompts given in the question.

\subsubsection{Feedback Questionnaire}

This questionnaire is adapted from the "Playing Tabletop Games to Learn English: Feedback Questionnaire for Game-Based Learning Activities" by Wang [25]. After the ten-week tabletop game teaching experiment was over, students in the experimental group were asked to fill out this questionnaire. This questionnaire is divided into two parts: "Likert's four-point scale" and "Multiple Choice and Open-ended Opinion Statement".

\section{Research Results and Discussion}

The purpose of this study is to explore the progress the students can make and their learning retention. After the students took the tests before and after the experiment as well as the delayed test after the experiment, the independent sample t-test was used to compare the scores the two groups got in the three tests. Then, the dependent sample $t$ test was used to analyze the progress the two groups made based on the scores they got in the three tests. In addition, the feedback questionnaires filled out by students were analyzed by means of averages and percentages.

\subsection{Effectiveness of Learning "Listening Comprehension of English Vocabulary"}

\subsubsection{Differences in the Scores Each Group Got in the} Pre-Test and Post-Test for Listening Comprehension of English Vocabulary

After the students have received ten weeks of English vocabulary teaching, they took the post-test. Then, the dependent sample t test in SPSS was used to analyze the difference of each group's performances in pre-test and post-test.

\subsubsection{Experimental Group}

The average of the scores the experimental group got in the post-test was 46.8 points, which was 5.2 points better than that in pre-test, and there was a significant improvement $(t=-3.213, p=.005)$, as shown in Table 3. Therefore, reviewing vocabulary using tabletop games after English teaching class can effectively improve the students' listening comprehension of English vocabulary.

Table 3. Comparison of scores the two groups of students got in the test before the experiment

\begin{tabular}{|c|c|c|c|c|}
\hline $\begin{array}{c}\text { Listening } \\
\text { comprehension }\end{array}$ & Average & $\begin{array}{c}\text { Standard } \\
\text { deviation }\end{array}$ & $\boldsymbol{t}$ & $\begin{array}{c}\text { Significance } \\
\text { (two-tailed) }\end{array}$ \\
\hline Pre-test & 41.60 & 7.94 & \multirow{2}{*}{-3.213} & $.005^{*}$ \\
\hline Post-test & 46.80 & 1.88 & & \\
\hline
\end{tabular}

" $p<.05$

\subsubsection{Control Group}

The average of the scores the control group got in the post-test was 46.18 points, which was 6.73 points better than that in pre-test, and there was a significant improvement ( $t=-3.345, p=.003)$, as shown in Table 4 . Therefore, reviewing vocabulary using writing and recitation method after English teaching class can effectively improve the students' listening comprehension of English vocabulary.

Table 4. Progress the control group made based on pre-test and post-test for listening comprehension of English vocabulary

\begin{tabular}{|c|c|c|c|c|}
\hline $\begin{array}{c}\text { Listening } \\
\text { comprehension }\end{array}$ & Average & $\begin{array}{c}\text { Standard } \\
\text { deviation }\end{array}$ & $\boldsymbol{t}$ & $\begin{array}{c}\text { Significance } \\
\text { (two-tailed) }\end{array}$ \\
\hline Pre-test & 39.45 & 10.92 & \multirow{2}{*}{-3.345} & $.003^{*}$ \\
\hline Post-test & 46.18 & 3.20 & & \\
\hline
\end{tabular}

${ }^{*} p<.05$

\subsubsection{Comparison of the Progress the Two Groups Made in} Listening Comprehension of English Vocabulary

According to Table 5, the comparison between the two groups' performances in the post-test indicates that there is no statistically significant difference ( $t=0.771, p=.446)$ between the two groups. Based on this result, it can be inferred that both using tabletop games and using writing practice for reviewing English vocabulary after class can achieve the effectiveness of practice and improve the learning performance of students in listening comprehension of English vocabulary.

Table 5. Comparison between the two groups' performances in the immediate post-test for listening comprehension of English vocabulary

\begin{tabular}{|c|c|c|c|c|}
\hline Group & Average & $\begin{array}{c}\text { Standard } \\
\text { deviation }\end{array}$ & $\boldsymbol{t}$ & $\begin{array}{c}\text { Significance } \\
\text { (two-tailed) }\end{array}$ \\
\hline $\begin{array}{c}\text { Experimental } \\
\text { group }\end{array}$ & 46.80 & 1.88 & \multirow{2}{*}{0.771} & .446 \\
\cline { 1 - 3 } Control group & 46.18 & 3.20 & & \\
\hline
\end{tabular}




\subsubsection{Learning Retention of the Two Groups' Listening} Comprehension of English Vocabulary

As shown in Table 6, the comparison between the two groups' performances in the post-test and delayed post-test indicates that there is no statistically significant difference $(t=0.771, p=.446$ ) between the two groups (experimental group: $t=0.438, p=.666$ ) (control group: $t=0.326, p$ $=.747$ ). Based on this result, it can be inferred that both teaching methods using tabletop games and using writing practice can make students effectively link the meaning and pronunciation of vocabulary, and effectively retain what they have learned in their minds. In the comparison of the effect of learning retention between the two classes, as shown in Table 7, there is no significant difference between the two classes' performances in the delayed test $(t=0.468, p=.643)$.

In summary, there is a significant difference between the two groups' performances before and after the teaching of listening comprehension of English vocabulary. However, on comparison, there is no significant difference between the two groups' progress and learning retention. As shown in Figure 2, both vocabulary teaching methods can promote students' progress and learning retention.

Table 6. Two groups' performances in the post-test and delayed post-test for listening comprehension of English vocabulary

\begin{tabular}{|c|c|c|c|c|c|}
\hline \multicolumn{2}{|c|}{ Group } & Average & Standard deviation & $\boldsymbol{t}$ & Significance (two-tailed) \\
\hline \multirow{2}{*}{ Experimental group } & Post-test & 46.80 & 1.88 & \multirow{2}{*}{0.438} & .666 \\
\cline { 2 - 6 } & Delayed post-test & 46.50 & 2.67 & & \multirow{2}{*}{0.326} \\
\hline \multirow{2}{*}{ Control group } & Post-test & 46.18 & 3.20 & .747 \\
\cline { 2 - 6 } & Delayed post-test & 46.00 & 4.05 & \\
\hline
\end{tabular}

Table 7. Comparison between the two groups' performances in delayed post-test for listening comprehension of English vocabulary

\begin{tabular}{|c|c|c|c|c|}
\hline Group & Average & Standard deviation & $\boldsymbol{t}$ & Significance (two-tailed) \\
\cline { 1 - 3 } Experimental group & 46.50 & 2.67 & \multirow{2}{*}{0.468} & .643 \\
\hline Control group & 46.00 & 4.05 & & \\
\hline
\end{tabular}

$\rightarrow$ Experimental group

- $\$$ - Control group

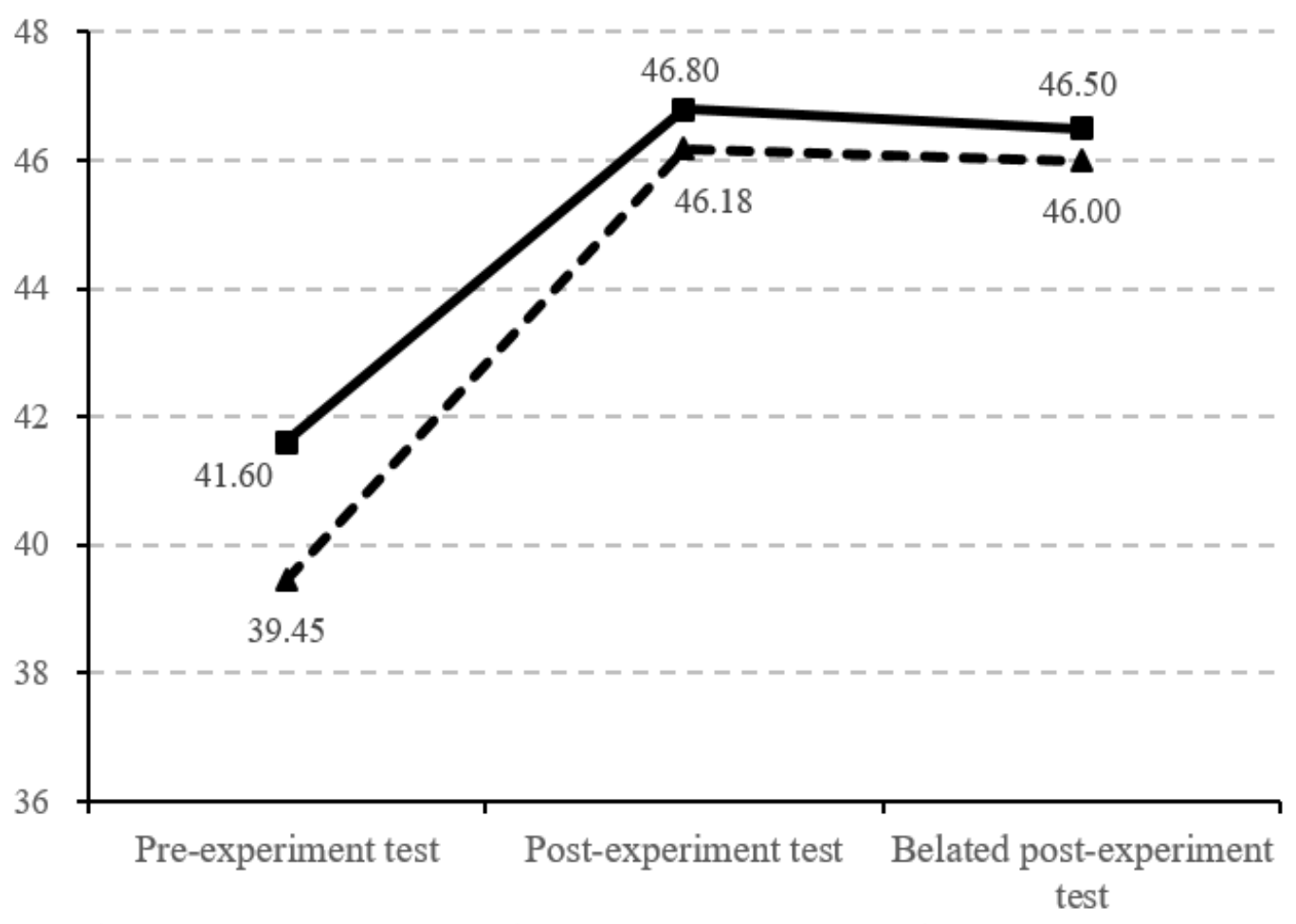

Figure 2. Comparison between the two groups' test scores for listening comprehension of English vocabulary 


\subsection{Effectiveness of Learning "Spelling"}

\subsubsection{Progress Each Group Made Based on Students' Performances in Pre-Test and Post-Test}

The test was drawn up based on the core vocabulary and alphabet examples of vocabulary in Lesson 3 and Lesson 4 of Book 1. The purpose is to know students' listening comprehension of English vocabulary. Twelve words were selected for the questions. The teacher read the word, and the subjects were required to select the correct picture corresponding to the word they heard.

\subsubsection{Experimental Group}

As shown in Table 8, the average of the scores the experimental group got in the post-test was 37.6 points, which was 31 points higher than that in pre-test, and there was a significant improvement $(t=-9.164, p<.001)$. Therefore, reviewing vocabulary using tabletop games after English teaching class can effectively improve the students' ability to spell English vocabulary.

Table 8. Progress the experimental group made based on pre-test and post-test for spelling English vocabulary

\begin{tabular}{|c|c|c|c|c|}
\hline Spelling & Average & $\begin{array}{c}\text { Standard } \\
\text { deviation }\end{array}$ & $\boldsymbol{t}$ & $\begin{array}{c}\text { Significance } \\
\text { (two-tailed) }\end{array}$ \\
\cline { 1 - 3 } Pre-test & 6.60 & 10.08 & \multirow{2}{*}{-9.164} & \multirow{2}{*}{$.005^{*}$} \\
\cline { 1 - 3 } Post-test & 37.60 & 16.64 & & \\
\hline
\end{tabular}

${ }^{*} p<.05$

\subsubsection{Control Group}

As shown in Table 9, the average of the scores the control group got in the post-test was 33.45 points, which was 22 points higher than that in pre-test, and there was a significant improvement $(t=-6.742, p<.001)$. Therefore, reviewing vocabulary using writing method after English teaching class can effectively improve the students' ability to spell English vocabulary.

Table 9. Progress the control group made based on pre-test and post-test for spelling English vocabulary

\begin{tabular}{|c|c|c|c|c|}
\hline Spelling & Average & $\begin{array}{c}\text { Standard } \\
\text { deviation }\end{array}$ & $\boldsymbol{t}$ & $\begin{array}{c}\text { Significance } \\
\text { (two-tailed) }\end{array}$ \\
\hline Pre-test & 11.45 & 17.38 & \multirow{2}{*}{-6.742} & $.003^{*}$ \\
\hline Post-test & 33.45 & 18.00 & & \\
\hline
\end{tabular}

${ }^{*} p<.05$

\subsubsection{Comparison of the Progress the Two Groups Made in Spelling}

According to Table 10, the comparison between the two groups' performances in the post-test indicates that there is no statistically significant difference $(t=0.773, p=.444)$ between the two groups. Based on this result, it can be inferred that both using tabletop games and using writing practice for reviewing English vocabulary can effectively improve the students' ability to spell English vocabulary.
Table 10. Comparison between the two groups' performances in the immediate post-test for spelling

\begin{tabular}{|c|c|c|c|c|}
\hline Group & Average & $\begin{array}{c}\text { Standard } \\
\text { deviation }\end{array}$ & $\boldsymbol{t}$ & $\begin{array}{c}\text { Significance } \\
\text { (two-tailed) }\end{array}$ \\
\hline $\begin{array}{c}\text { Experimental } \\
\text { group }\end{array}$ & 37.60 & 16.64 & \multirow{2}{*}{0.773} & \multirow{2}{*}{.444} \\
\cline { 1 - 3 } Control group & 33.45 & 18.00 & & \\
\hline
\end{tabular}

\subsubsection{Two Groups' Learning Retention of Spelling}

According to Table 11, the comparison between the experimental group's performances in the post-test and delayed post-test indicates that there is significant difference ( $t=3.343, \quad p=.003)$ between the two performances. Similarly, there is significant difference between the control group's performances in the two tests ( $t=3.126, p=.005)$. The students have not studied English for a month of winter vacation. Their memories for English vocabulary have obviously faded, and there has been a significant decline in all the students' ability to spell English vocabulary. In addition, it can be seen from Table 12 that there is no significant difference between the two groups' performances in the delayed post-test. Both classes of students have forgotten part of English vocabulary they have learned. It can be inferred that students need to practice repeatedly to remember clearly the knowledge they have learned whether they use tabletop games or writing practice for review. Just like the forgetting curve proposed by Ebbinghaus, the new vocabulary learned needs to be consciously reviewed time and again, so that they will remain in our long-term memory [10].

Table 11. Two groups' performances in the post-test and delayed post-test for spelling

\begin{tabular}{|c|c|c|c|c|c|}
\hline \multicolumn{2}{|c|}{ Group } & Average & $\begin{array}{l}\text { Standard } \\
\text { deviation }\end{array}$ & $t$ & $\begin{array}{l}\text { Significance } \\
\text { (two-tailed) }\end{array}$ \\
\hline \multirow{2}{*}{$\begin{array}{l}\text { Experimental } \\
\text { group }\end{array}$} & Post-test & 37.60 & 16.64 & \multirow[b]{2}{*}{3.343} & \multirow[b]{2}{*}{$.003^{*}$} \\
\hline & \begin{tabular}{|l|} 
Delayed \\
post-test
\end{tabular} & 31.00 & 17.36 & & \\
\hline \multirow[b]{2}{*}{ Control group } & Post-test & 33.45 & 18.00 & \multirow[b]{2}{*}{3.126} & \multirow[b]{2}{*}{$.005^{*}$} \\
\hline & \begin{tabular}{|l|} 
Delayed \\
post-test
\end{tabular} & 28.27 & 17.93 & & \\
\hline
\end{tabular}

${ }^{*} p<.05$

Table 12. Comparison between the two groups' performances in delayed post-test for spelling

\begin{tabular}{|c|c|c|c|c|}
\hline Group & Average & $\begin{array}{c}\text { Standard } \\
\text { deviation }\end{array}$ & $\boldsymbol{t}$ & $\begin{array}{c}\text { Significance } \\
\text { (two-tailed) }\end{array}$ \\
\hline $\begin{array}{c}\text { Experimental } \\
\text { group }\end{array}$ & 31.00 & 17.36 & \multirow{2}{*}{-0.500} & .620 \\
\hline Control group & 28.27 & 17.93 & & \\
\hline
\end{tabular}

${ }^{*} p<.05$

The researcher turned the data on students' performances in pre-test, post-test and delayed post-test for spelling into a graph as shown in Figure 3. It can be seen that the use of tabletop games and traditional writing practice methods to review English vocabulary can 
improve students' spelling skills. Although there is no statistically significant difference in the progress the two groups have made, it can be seen that the experimental group using tabletop games to review vocabulary made more progress and got more scores than the control group. But after a winter vacation, due to the lack of language learning situations and practice, both groups have forgotten part of English vocabulary they have learned. As stated by Nagy [26], when students were deeply immersed in a foreign language, their vocabulary would be expanded. However, because English is not an official language of Taiwan, it is necessary to deliberately create a language learning environment. Writing practice still can help students review the knowledge they have learned. If students do not review the knowledge they have learned regularly, they will forget it over time according to the degeneration theory [9].

\subsection{Analysis of Feedback Questionnaire on Learning Attitudes}

\subsubsection{Analysis of Students' Attitudes towards Learning English Vocabulary}

The 4-point Likert scale was used in this questionnaire. Questions 1-3 were designed to find students' attitudes towards learning English. The average score is 3.18, which shows that students have a positive attitude towards English learning. Among them, the first question "I think learning vocabulary is very important to improve English proficiency." The average score is 3.55, showing that students have a highly positive attitude. Although they understand this, the average score of the students' feedback in the second question "I usually like to memorize vocabulary." is only 2.65. It can be seen that although students know that English proficiency is important, their motivation for vocabulary learning is low, as shown in Table 13.

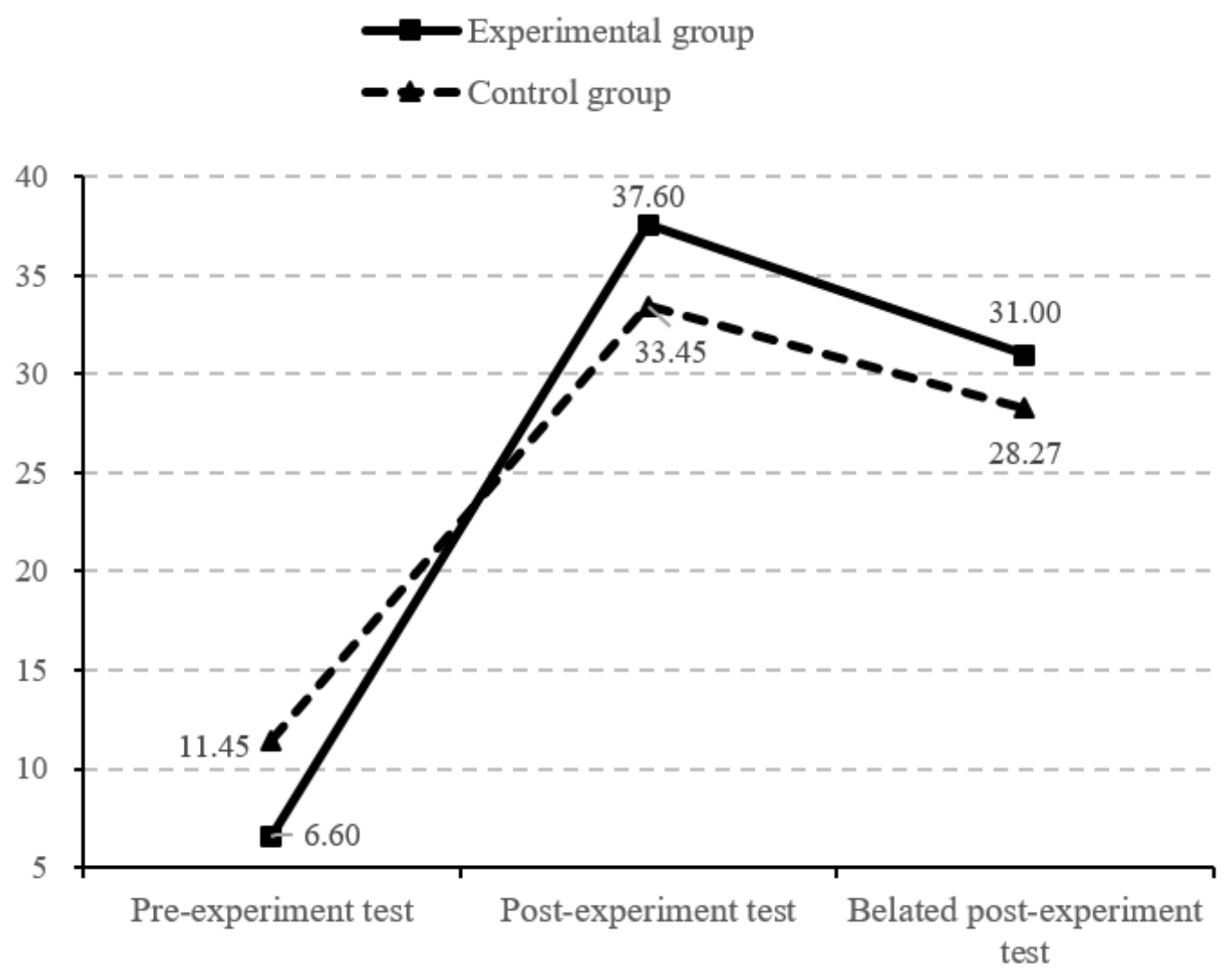

Figure 3. Comparison of the scores the two groups got in spelling ability tests

Table 13. Students' attitudes towards learning English

\begin{tabular}{|l|c|c|c|c|c|}
\hline \multicolumn{1}{|c|}{ Question } & Strongly agree & Agree & Disagree & Strongly disagree & \multirow{2}{*}{ Average } \\
\cline { 2 - 5 } & $\mathrm{n}(\%)$ & $\mathrm{n}(\%)$ & $\mathrm{n}(\%)$ & $\mathrm{n}(\%)$ & $2(10)$ \\
\hline $\begin{array}{l}\text { 1. I think learning vocabulary is very } \\
\text { important to improve English proficiency. }\end{array}$ & $15(75)$ & $3(15)$ & $0(0)$ & 3.55 \\
\hline 2. I usually like to memorize vocabulary. & $6(30)$ & $4(20)$ & $7(35)$ & $3(15)$ & 2.65 \\
\hline 3. I want to know more vocabulary. & $11(55)$ & $5(25)$ & $4(20)$ & $0(0)$ & 3.35 \\
\hline \multicolumn{7}{|c|}{ Average score of questions 1-3 } & & 3.18 \\
\hline
\end{tabular}

Note: $\mathrm{n}$ = Number of students 
4.3.2. Analysis of students' attitudes towards the tabletop games integrated into English vocabulary teaching

It can be seen from Table 14 that students' views on the tabletop games integrated into English vocabulary review. The overall average score is 3.22 , indicating that students have a positive attitude towards this course. The fourth question "I think learning vocabulary through "English vocabulary tabletop games" is very interesting." The average score is 3.75. Students strongly agree that tabletop games can bring fun to learning and increase students' learning motivation. As mentioned by Hsu and Ouyang [19], the elements of tabletop games are rules, game pieces and fun. Students really have fun playing tabletop games in the class.

It is worth mentioning that this course has increased students' confidence in learning English vocabulary. The average score of the group of questions from the 9th to 14th question is 3.35. It can be seen that students were more confident of memorizing vocabulary while playing tabletop games. Nakamura \& Csikszentmihalyi [27] mentioned that the elements of flow include a conscious sense of self-control. Students were confident that they could memorize vocabulary well while playing tabletop games, which enhanced their sense of control.

Table 14. Students' attitudes towards the tabletop games integrated into English vocabulary teaching

\begin{tabular}{|c|c|c|c|c|c|}
\hline \multirow{2}{*}{ Question } & $\begin{array}{c}\text { Strongly } \\
\text { agree }\end{array}$ & Agree & Disagree & $\begin{array}{l}\text { Strongly } \\
\text { disagree }\end{array}$ & \multirow[t]{2}{*}{ Average } \\
\hline & $\mathrm{n}(\%)$ & $\mathrm{n}(\%)$ & $\mathrm{n}(\%)$ & $\mathrm{n}(\%)$ & \\
\hline \begin{tabular}{|l}
4. I think learning vocabulary through \\
vocabulary tabletop games is very interesting.
\end{tabular} & $16(80)$ & $3(15)$ & 1(5) & $0(0)$ & 3.75 \\
\hline $\begin{array}{l}\text { 5. The tabletop games integrated into English } \\
\text { vocabulary activities can help me save time for } \\
\text { memorizing vocabulary. }\end{array}$ & $12(60)$ & $3(15)$ & $1(5)$ & $4(20)$ & 3.15 \\
\hline $\begin{array}{l}\text { 6. Playing English vocabulary tabletop games helps me } \\
\text { memorize English vocabulary more effectively. }\end{array}$ & $12(60)$ & $5(25)$ & $1(5)$ & $2(10)$ & 3.35 \\
\hline $\begin{array}{l}\text { 7. It is easier to memorize English vocabulary after } \\
\text { playing English vocabulary tabletop games. }\end{array}$ & 13(65) & $3(15)$ & $2(10)$ & $2(10)$ & 3.35 \\
\hline $\begin{array}{l}\text { 8. After playing the English vocabulary tabletop game, I } \\
\text { get a better score in English vocabulary test. }\end{array}$ & $11(55)$ & $4(20)$ & $3(15)$ & $2(10)$ & 3.20 \\
\hline $\begin{array}{l}\text { 9. After playing English vocabulary tabletop games, I } \\
\text { feel that I am more capable of memorizing English } \\
\text { vocabulary. }\end{array}$ & $11(55)$ & $6(30)$ & $2(10)$ & 1(5) & 3.35 \\
\hline $\begin{array}{l}\text { 10. I would recall the spelling of vocabulary when } \\
\text { playing games, to help me write the answer in a } \\
\text { vocabulary test. }\end{array}$ & $9(45)$ & $6(30)$ & $3(15)$ & $2(10)$ & 3.10 \\
\hline $\begin{array}{l}\text { 11. Playing English vocabulary tabletop games helps me } \\
\text { learn more new vocabulary. }\end{array}$ & $13(65)$ & $5(25)$ & $1(5)$ & 1(5) & 3.50 \\
\hline $\begin{array}{l}\text { 12. Playing English vocabulary tabletop games } \\
\text { increases my confidence in memorizing vocabulary. }\end{array}$ & $12(60)$ & $5(25)$ & $1(5)$ & $2(10)$ & 3.35 \\
\hline $\begin{array}{l}\text { 13. Playing English vocabulary tabletop games makes } \\
\text { me want to memorize English vocabulary even more. }\end{array}$ & $9(45)$ & $8(40)$ & $2(10)$ & 1(5) & 3.25 \\
\hline $\begin{array}{l}\text { 14. Playing English vocabulary tabletop games lets me } \\
\text { know different ways to memorize vocabulary. }\end{array}$ & $11(55)$ & $5(25)$ & $4(20)$ & $0(0)$ & 3.35 \\
\hline $\begin{array}{l}\text { 15. Playing English vocabulary tabletop games makes } \\
\text { me feel that memorizing English vocabulary is very } \\
\text { important. }\end{array}$ & $11(55)$ & $4(20)$ & $2(10)$ & $3(15)$ & 3.15 \\
\hline $\begin{array}{l}\text { 16. Playing English vocabulary tabletop games makes } \\
\text { me like memorizing English vocabulary more. }\end{array}$ & $6(30)$ & $4(20)$ & $6(30)$ & $4(20)$ & 2.60 \\
\hline $\begin{array}{l}17 \text { I still find it difficult to memorize English } \\
\text { vocabulary After playing tabletop games for learning } \\
\text { English vocabulary. }\end{array}$ & $4(20)$ & $3(15)$ & $4(20)$ & $9(45)$ & 3.10 \\
\hline $\begin{array}{l}\text { 18. Playing English vocabulary tabletop games is not } \\
\text { helpful for memorizing vocabulary at all. }\end{array}$ & $4(20)$ & $3(15)$ & $3(15)$ & $10(50)$ & 3.15 \\
\hline $\begin{array}{l}\text { 19. Playing English vocabulary tabletop games puts me } \\
\text { under pressure to study. }\end{array}$ & $2(10)$ & $1(5)$ & $5(25)$ & $12(60)$ & 3.40 \\
\hline $\begin{array}{l}\text { 20. I think it is exams that make me to memorize English } \\
\text { vocabulary. }\end{array}$ & $4(20)$ & $6(30)$ & $3(15)$ & $7(35)$ & 3.15 \\
\hline \multicolumn{5}{|c|}{ Average score of questions $4-20$} & 3.22 \\
\hline
\end{tabular}


Table 15. Open-ended feedback on question 21 in the questionnaire $(n=20)$

\begin{tabular}{|l|c|c|}
\hline \multicolumn{1}{|c|}{ Question } & Number of students & \% \\
\hline \multicolumn{1}{|c|}{ Yes } & $\mathrm{n}$ & $\%$ \\
\hline \multicolumn{1}{|c|}{ No } & 18 & 90 \\
\hline \multicolumn{1}{|c|}{ Reasons why they are fun: (can select multiple answers) } & 2 & 10 \\
\hline 1. Can help memorize English vocabulary. & 16 & 80 \\
\hline 2. It is a joy to be able to play with classmates. & 18 & 90 \\
\hline 3. Able to demonstrate my proficiency in English vocabulary. & 14 & 70 \\
\hline 4. Winning the game or getting high scores gives a sense of achievement. & 16 & 80 \\
\hline 5. Can get rewards after the game. & 12 & 60 \\
\hline 6. It's easy and stress-free when playing games. & 14 & 70 \\
\hline Why it is not fun: Because some games are not fun. & 1 & 5 \\
\hline
\end{tabular}

Table 16. Open-ended feedback on question 22 in the questionnaire $(n=20)$

\begin{tabular}{|c|c|c|}
\hline Question & Number of students & $\%$ \\
\hline $\begin{array}{l}\text { 22. Overall, do you think that playing "English vocabulary tabletop games" helps your memorized English } \\
\text { vocabulary? }\end{array}$ & $\mathrm{n}$ & $\%$ \\
\hline Yes & 16 & 80 \\
\hline No & 4 & 20 \\
\hline \multicolumn{3}{|l|}{ My harvests: (can select multiple answers) } \\
\hline $\begin{array}{l}\text { 1. When taking the vocabulary test, the spelling image during the game will come to my mind to help me } \\
\text { remember. }\end{array}$ & 16 & 80 \\
\hline 2. When playing games with classmates, we can encourage each other. & 15 & 75 \\
\hline 3. Because I want to win a game or get a high score, it will make me more attentive. & 16 & 80 \\
\hline 4. The games are fun and make me involve myself in them. & 14 & 70 \\
\hline 5. Playing games makes me more impressed with English vocabulary. & 18 & 90 \\
\hline 6. It makes me more confident that I can memorize English vocabulary. & 17 & 85 \\
\hline 7. Makes me more interested in memorizing English vocabulary. & 15 & 75 \\
\hline 8. Other & 0 & 0 \\
\hline
\end{tabular}

\subsubsection{Analysis of Open-end Questions}

Questions 21 and 22 in the questionnaire are open-ended. Students in the experimental group can express qualitative opinions by answering the open-ended questions. The analysis of students' answers is described in table 15.

As shown in Table 15, there were 18 students who thought tabletop games were fun, accounting for $90 \%$ of the total. Most students felt tabletop games were very interesting. Among the reasons why they felt tabletop games were fun, $90 \%$ of students thought that it was a pleasure to play games with their peers. This is consistent with the theories of play mentioned in the literature review section. Playing games helps children learn and expand experience. Students can also learn interpersonal communication and problem-solving skills by playing games [17].

Eighty percent of the students thought that tabletop games can help memorize vocabulary and enhance their sense of achievement. Nakamura \& Csikszentmihalyi [27] mentioned that the elements of flow include immediate feedback. Getting a high score in the game indicates that it makes students get immediate feedback. Students who feel a sense of achievement refers to the inner reward. According to the students' open-ended answers, it can be understood that tabletop games can effectively bring students into a state of flow, and enhance their sense of achievement and efficiency in learning.

According to Table 16, it can be concluded that $80 \%$ of the students thought that playing "English vocabulary tabletop games" was helpful for memorizing English vocabulary. Among "my harvest options", 90\% of the students thought that "playing tabletop games for learning English vocabulary" could strengthen their impression of vocabulary. Eighty-five percent of students thought that this course could increase their confidence in memorizing vocabulary, and $80 \%$ of the students agreed that "English vocabulary tabletop games" could help them recall the 
vocabulary when taking tests, and made them more attentive because they wanted to get a high score in the game. This is in line with the way of entering the flow. To pursue internal rewards, learners get into a state of total concentration [28].

In summary, although the quantitative research results did not indicate the difference in learning effectiveness between the two groups, it can be known that the students in the experimental group had a positive view of this course according to the feedback from the questionnaire. Based on the analysis of the data on the feedback questionnaire, it can be seen that students had a positive attitude towards the tabletop games integrated into English vocabulary teaching. Students also strongly agreed that this course was interesting and it was pleasant to play tabletop games with classmates. Just like the theories of play mentioned in the literature review section, playing games not only provides educational functions, but also helps students develop interpersonal skills and improve children's concentration and problem-solving skills [14]. With textbooks suitable for students' level, playing tabletop games can allow students to get into a state of flow, allowing students to feel a sense of achievement and satisfaction in the learning process.

\section{Conclusions and Recommendations}

\subsection{Conclusions}

5.1.1. Both the Experimental Group and the Control Group Have a Significant Improvement in Their "Listening Comprehension of English Vocabulary"

After receiving ten weeks of English vocabulary teaching, both the experimental group and the control group have made significant progress based on the comparison between each group's performances in the pre-test and post-test for "listening comprehension of English vocabulary". It can be seen that both tabletop games and writing exercises can improve students' "listening comprehension of English vocabulary". In addition, the standard deviations of both groups have decreased, which means that both teaching methods can narrow the gap between the levels of students. On the other hand, the scores the experimental group got in the post-test were not significantly higher than those of the control group. Accordingly, it can be inferred that the effect of tabletop games integrated into English teaching is equivalent to those writing exercises. According to the results of this research, there is no significant difference between each group's performances in the immediate post-test and the delayed post-test given after the winter vacation. It can be seen that both teaching methods can improve students' learning retention of "listening comprehension of English vocabulary".
5.1.2. The Progress the Experimental Group Made Greater Than the Control Group in Spelling Tests

\subsubsection{Both Groups Made Significant Progress in "Spelling" Ability}

According to the results of the research, both groups have made significant progress in the post-test. Although there is no significant difference in the test scores between the two classes, it can be seen that the progress the experimental group made is greater than the control group. Therefore, it is obvious that the tabletop games integrated into English vocabulary teaching can effectively help students overcome the difficulties with spelling and improve the effectiveness of students' learning English vocabulary.

\subsubsection{Two Groups' Learning Retention of "Spelling" Has not been Improved}

Both groups have taken the delayed post-test after winter vacation. Compared with their performances in the post-test, both groups got much less scores in the delayed post-test. As a result, regardless of tabletop games or writing exercises, continuous review and use of English are very important. Regular review is the only way to improve learning retention.

\subsubsection{Students in the Experimental Group Have a Positive Attitude towards Tabletop Games Integrated into English Teaching}

According to the analysis of data from feedback questionnaire, it can be seen that the students in the experimental group had a positive attitude towards English learning, but even though they knew the importance of learning English, they did not like to memorize English vocabulary. After this experimental course, students have a positive attitude towards tabletop games integrated into English teaching. Most of the students liked playing tabletop games to learn English. One of the main reasons was that tabletop games brought them fun, strengthened their impression of vocabulary, increased their confidence in memorizing vocabulary, and allowed them to learn different ways of memorizing vocabulary. In addition, according to their answers to the open-ended questions, most students thought that tabletop games integrated into English teaching was fun, allowing students to get into successfully flow state and feel a sense of pleasure. Based on the analysis of the data from questionnaire, it can be understood that tabletop games can effectively improve students' confidence and satisfaction in English learning.

\subsection{Recommendations}

Based on the findings and discussion of the research results, the recommendations provided for teachers and future related research for reference are listed as follows. 


\subsubsection{Recommendations for Teachers}

\subsubsection{Teachers Can Use Tabletop Games in the English Classroom}

Although the research results show that there is no significant difference in learning effectiveness between the experimental group and the control group, the experimental group has made significant progress in learning effectiveness. It is worth mentioning that students have a positive attitude towards the tabletop games integrated into English vocabulary teaching course and strongly agree that the course can bring a lot of fun to them. As the saying from Confucius: "They who love it are better than those who know it, and they who delight in it are better than those who love it. When students feel interested in the course, the learning atmosphere in the class will be more enthusiastic and students can learn in a happy environment. Therefore, according to the research results, it is believed that integrating tabletop games into English class is a feasible teaching activity. The tabletop games integrated to English vocabulary teaching can be adopted for teaching English sentence patterns and English conversations etc., allowing students to learn English through games thoroughly. In addition, due to the prevalence of electronic textbooks in recent years, students have often been exposed to virtual tabletop games on the screen. Teachers can design tabletop games using computers to allow students to practice English and help themselves avoid having to design and make teaching tools for tabletop games.

While using games for teaching, it should be remembered that traditional writing exercises can also help students strengthen the impression of learning and achieve good learning results. Teachers can use writing exercises combined with tabletop games to achieve better results for students' learning.

\subsubsection{The Teaching Method of Integrating Tabletop Games into English Course}

When preparing lessons, teachers should choose activities closely related to the teaching goals. Tabletop games are a medium for students to practice English. The goal of the course is to help students achieve their learning goals. Therefore, when choosing or designing tabletop games, teachers should consider the characteristics and levels of the students in the class, so as to choose the tabletop game that is most suitable for the students. The research results showed that there was obvious drop in students' learning retention when taking spelling test. Therefore, when designing tabletop games, teachers should strengthen the effectiveness of delayed memory in spelling.

In the classroom, when preparing to play the game, the teacher should first explain the rules of the game to students and give demonstrations to let students understand the way the game is played. In the process of the game, when the students are already familiar with the game, the teacher can increase the game difficulty gradually to make the game more challenging and increase the students' willingness to play.

\subsubsection{Interpersonal Interaction of Integrating Tabletop Games into English Course}

Before conducting the course, the teachers may invite students to make tabletop game pieces together. Teachers and students can complete tasks together, which can enhance the teacher-student friendship. Students will also cherish game pieces more. During the game, the teacher can choose a team leader to help collect and manage the game pieces and paper trays, and the team leader can lead the team members to play the game together and make the game run smoothly. When students are playing games, teachers can walk through the aisle and observe each group's activities and give guidance and encouragement to help students use English in the game. Some students may vent their dissatisfaction on their group members because they worry too much about gain and loss. Noticing this, teachers need to teach students to respect each other and have a positive attitude to the win or lose of every game, and the manner of dealing with others.

\subsubsection{Recommendations for Follow-up Research}

\subsubsection{Both Groups Made Significant Progress in "Spelling" Ability}

According to the results of the research, both groups have made significant progress in the post-test. Although there is no significant difference in the test scores between the two classes, it can be seen that the progress the experimental group made is greater than the control group. Therefore, it is obvious that the tabletop games integrated into English vocabulary teaching can effectively help students overcome the difficulties with spelling and improve the effectiveness of students' learning English vocabulary.

\subsubsection{Recommendations for Follow-up Research}

\subsubsection{Research Subjects}

All the subjects of this study are students in third grade of an elementary school in Tainan City. Therefore, it is difficult to apply the research results to students in other grades due owing to the differences in the characteristics and prior knowledge of the students in different grades. It is suggested that the subjects can be enlarged to include students in other grades for future research, to understand the effect of the application of tabletop games in English teaching in other grades.

\subsubsection{Research Methods}

The quasi-experimental method and questionnaire survey were used for this research to explore the progress the students made based on their performances in the 
pre-test and post-test and learning attitudes before and after the test. Although the method helps researchers to know the difference in scores statistically, it is difficult to know the entire teaching process. It is recommended that the action research approach can be adopted for relevant research in the future, to allow teachers to have a deeper understanding of the students' ideas and interaction among them based on interview records and reflections on the teaching process.

\subsubsection{Research Variables}

English proficiency includes listening, speaking, reading, writing and other abilities. This research only focuses on listening comprehension of English vocabulary and spelling skills. It is recommended that future research variables be directed towards the exploration of language skills such as sentence patterns and conversations to enrich the research on tabletop games used for English teaching.

\section{REFERENCES}

[1] M. Y. Lo. "Taipei, New Taipei and Tainan in front: Bilingual education,” Ettoday News, http://www.ettoday.net/news/20190903/1524377.htm (accessed Feb. 9, 2021)

[2] Ministry of Education. "Bilingual Nation 2030," Ministry of Education, 2018.

[3] R. C. T. Lee. "There is no shortcut to learning English (2nd ed.),” Linking Publishing, 2017.

[4] J. Hadfield, C. Hadfield. "Introduction to teaching English," Oxford University Press, 2008.

[5] B. Laufer. "Second language vocabulary acquisition from language input and from formfocused activities," Language Teaching, vol. 42, no. 3, pp. 341-354, 2009. DOI: $10.1017 / S 0261444809005771$

[6] Ministry of Education. "Curriculum Guidelines of 12-Year Basic Education,” Ministry of Education, Taiwan, 2014.

[7] R. J. Sternberg, W. M. Williams. "Educational Psychology (2nd ed.),” Pearson, 2009.

[8] C. B. Chang. "Teaching theories and methods," Psychological Publishing Co., Ltd., 2018.

[9] R. E. Slavin. "Educational Psychology: Theory and Practice,” Allyn and Bacon, 1997.

[10] C. H. Chang. “Educational Psychology,” Tung Hua Book Co., Ltd., 2013.

[11] E. Hatch, C. Brown. "Vocabulary, semantics, and language Education,” Cambridge University Press, 2000.

[12] N. Schmitt, D. Schmitt. "Vocabulary in language teaching," Cambridge University Press, 2020.

[13] C. C. Liang. “Games are not just games: Talking about children's cognitive development and learning from the theory of games,” Taiwan Education Review, no. 698, pp. 39-41, 2016.

[14] P. C. Kao, Y. L. Chen. "Exploring the Relationship between Play and Children Development-Theory and Practice," Sports Research Review, no. 113, pp. 15-21, 2011. DOI: 10.6162/SRR.2011.113.03

[15] J. Moyles. "Supporting play-based teaching thriough collaborative practice-based research," Support for Learning, vol. 15, no. 4, pp. 159-164, 2003.

[16] Y. F. Yang. “Analysis of Piaget's Cognitive Development Game Theory,” Technology and Economic Guide, no. 32 pp. 116-117, 2016.

[17] J. E. Johnson, J. F. Christie, T. D. Yawkey, F. P. Wardle, Play and early childhood development. Scott Foresman \& Co., 1987.

[18] M. C. Chan. "Reflection on integrating board games into instruction," Taiwan Educational Review Monthly, vol. 9, no. 5, pp. 118-124, 2020.

[19] J. C. Hsu, L. C. Ouyang. "Board games class: It turns out that I play not only board games, but life," Yuan Liou Book Co., Ltd., 2016.

[20] J. P. Hinebaugh, “A board game Education,” Rowman \& Littlefield Press, 2009.

[21] H. P. Chan, C. C. Kuo, J. L. Lou. “A Study Using Board Game Teaching to Improve Interpersonal Relationship in Junior High School Classes,” NPUST Humanities and Social Sciences Research: Pedagogy, vol. 13, no. 1, pp. 21-48, 2019. DOI: 10.6618/HSSRP.201903_13(1).2

[22] T. J. Chiu. "Board games vs. English instruction,” The Educator Monthly, no. 579, pp. 69-72, 2015. DOI 10.6437/EM.201509_(579).0015

[23] C. F. Wu, S. C. Su. "Research on the Successful Factors of Using Board Game in Guided Teaching," Management Information Computing, vol. 8, no. 1, pp. 1-10, 2019. DOI: 10.6285/MIC.201903_8(1).0001

[24] C. T. Huang. "An Action Research on Integrating Board Games into English Instruction to Improve Third Graders' English Learning Motivation and Learning Achievement," http://hdl.handle.net/11296/snfqx6 (accessed Mar. 12, 2021).

[25] C. Y. Wang. "The Effects of Board Games on Taiwanese 6th Graders' English Spelling Ability," http:/hdl.handle.net/11296/8p2aun (accessed Mar. 16, 2021).

[26] W. E. Nagy. "On the role of context in first-and second-language vocabulary learning, Champaign, Ill.: University of Illinois at Urbana-Champaign,” Center for the Study of Reading, 1995.

[27] J. Nakamura, M. Csikszentmihalyi. "Flow theory and research, Handbook of positive psychology," Oxford University Press, 2009.

[28] G. Gerreyn. "Find your flow: helping students everyday lean into the struggle,” Teachers Matter, no. 42, pp. 44-45, 2019. 